\title{
Registratie aan de bron verlaten
}

\author{
Henk G. van der Poel
}

De NVU heeft besloten om de registratie van onder meer cystectomie- en prostatectomiepatiënten uit handen te geven. Geen registratie meer aan de bron, maar een derde partij die uit uw notities komt opmaken wie en hoe er geopereerd is. We kijken uit naar de resultaten. Wel hoop ik dat de directe spiegelingsinformatie, zoals die de laatste jaren ad hoc beschikbaar was, erin blijft. In de voorliggende uitgave van ons tijdschrift een overzicht van de resultaten van behandeling met PSMA-targeted isotopen. Ik hoop dat deze behandeling - die met veel enthousiasme vooralsnog met name in het buitenland gegeven wordt - ook in ons land beschikbaar komt, en dan wordt opgenomen in registraties.

Vanuit Utrecht beschrijft het tweede artikel in deze uitgave hoe de detrusorkracht bij een ouder wordende patiëntenpopulatie bij zowel mannen als vrouwen afneemt. Antistolling bij patiënten die een TURP ondergaan, kan tot secundaire bloedingen leiden en dit gebeurt bij bijna een kwart van de mannen. Deze be- vinding vraagt om nadere evaluatie van de vraag hoe lang met de antistollingsmedicatie in deze groep moet worden gestopt. Misschien dat we er als NVU ook goed aan doen om de TURP-ingrepen en de resultaten daarvan in een landelijke registratie vast te leggen om de procedure verder te verbeteren. Kortom, dankzij nauwkeurige evaluatie van Nederlandse resultaten kunnen we leren en inzicht krijgen in waar we ons vak verder kunnen verbeteren. Laten we vooral doorgaan met de registraties, het liefst aan de bron, direct in de kliniek.

Open Access This article is distributed under the terms of the Creative Commons Attribution 4.0 International License (http://creativecommons.org/licenses/by/4.0/), which permits unrestricted use, distribution, and reproduction in any medium, provided you give appropriate credit to the original author(s) and the source, provide a link to the Creative Commons license, and indicate if changes were made.

dr. Henk G. van der Poel, hoofdredacteur dr. H. G. van der Poel $(\bowtie)$

Tijdschrift voor Urologie, Bohn Stafleu van Loghum, Houten, Nederland

h.vd.poel@nki.nl 